\title{
ПСИХОЛОГІЧНИЙ СУПРОВІД ЕМПАТИЧНО-ТОЛЕРАНТНОГО СТАВЛЕННЯ ШКІЛЬНОГО КОЛЕКТИВУ БАТЬКІВ ДО ДІТЕЙ 3 ПСИХОФІЗИЧНИМИ ПОРУШЕННЯМИ
}

УдК: 616.853-052

\section{Царъкова Ольга Вікторівна \\ Доктор наук, дочент кафедри психологї Меліто- польського державного педагогічного університе- mу імені (Україна)}

\section{Пономаренко Вікторія Вікторівна}

Студентка другого курсу магістратури Мелітопольського державного педагогічного університеmу імені Б. Хмельницького, м. Мелітополь (Україна)

Анотація. Стаття присвячена визначенню змісту та суті психологічного супроводу формування емпатично-толерантного ставлення шкільного колективу батьків до дітей 3 психофізичними порушеннями в умовах впровадження інклюзивної освіти в Украӥні. Автори визначили значення емпатії та толерантності для ефективного функиіонування сучасного суспільства.

Проведено дослідження з батьками дітей в інклюзивному та звичайному класах загальноосвітньої школи. За даними дослідження можна зробити висновки, щуо в інклюзивному класі батьки не бачать перешкод для спільного навчання дітей обох категорій. В звичайному класі 50\% батьків заперечують інклюзивне навчання.

Саме тому головним завданням психолога в формуванні емпатично-толерантного ставлення шкільного колективу батьків до дітей $з$ психофізичними порушеннями $\epsilon$ консультативно-просвітницька робота.

Ключові слова: емпатичне ставлення, толерантне ставлення, психологічний супровід, інтеграція дітей з психофізичними порушеннями.

Постановка проблеми та її зв'язок 3 зичного та/або психічного здоров'я $\epsilon$ не лише важливими практичними завданнями. Повідображенням часу, але й представляє собою ширення в Україні процесу інклюзивного навще один крок до забезпечення повної реалізачання дітей з обмеженими можливостями фі- ції прав дітей з психофізичними порушеннями 
на якісну освіту. Інклюзивна практика реалізує доступ до одержання освіти в загальноосвітньому закладі за місцем проживання та створення необхідних умов для успішного навчання всіх без виключення дітей, незалежно від їх індивідуальних особливостей, психічних та фізичних можливостей. Збільшення кількості народження дітей із порушеннями в розвитку не лише проблема українського, але й глобального масштабу [3].

Аналіз останніх досліджень i публікацій. Такі автори, як А. Душка, Г. Кукуруза, В. Сорокін, О. Царькова в своїх працях розкривають проблему ставлення батьків до своїх дітей, які мають психофізичні порушення. Та в науковій літературі питання щодо виконання психологом завдань 3 надання просвітницької і консультативної допомоги саме шкільному колективу батьків в формуванні емпатично-толерантного ставлення до дітей $з$ психофізичними порушеннями висвітлюється досить обмежено. Основна увага приділяється коментарям та роз'ясненням основних положень щодо інклюзивної освіти «Саламанська декларація» 1994, стаття 24 «Освіта» Конвенції про права осіб з інвалідністю, Закон України «Про освіту» щодо особливостей доступу осіб з особливими освітніми потребами до освітніх послуг 2017, попередженню розвитку i поширенню будь-яких форм нетерпимості сприяє ст. 37 Конституції України 1996. Навіть в останніх публікаціях 3 проблем емпатично-толерантного ставлення до людей 3 психофізичними порушеннями, такі автори, як Ю. Бережко, Л. Байда, $\begin{array}{lll}\text { C. Буров, } & \text { В. Анзін, Я. Грибальський, }\end{array}$ Ю. Найда та інші достеменно не 3'ясовують зміст та сутність виконання психологом супроводу формування емпатично-толерантного ставлення людей до дітей 3 психофізичними порушеннями .

\section{Виділення невирішених раніше час-} тин загальної проблеми, якій присвячується стаття. Вивчення практичного стану проблеми інклюзії підтвердило нагальну необхідність спеціальної організації соціального середовища для включення дітей $з$ психофізичними вадами у спільну діяльність із здоровими однолітками в загальноосвітньому закладі.

Одними 3 учасників навчальновиховного процесу є батьки учнівського колективу, які формують у своїх дітей сприймання світу та ставлення до інших людей. Практика показує, що найбільш інтенсивно співпрацюють ті діти, батьки яких створили в родині сприятливий психологічний мікроклімат та служать для них прикладом доброзичливості і високої моральної культури. Важливим напрямком діяльності психолога виступає робота $з$ батьками, спрямована на формування у них емпатично-толерантного ставлення до дітей $з$ психофізичними порушеннями.

Матеріали і методи. Дослідження реальної ситуації проблеми ставлення до дітей з психофізичними порушеннями проводилось шляхом тестування (методики: тест комуніка- 
тивної толерантності опитувальник "Індекс толерантності"
Г. Солдатова,
О. Крвцова,
О. Хухлаєв,

Л. Шайгерова, методика діагностики рівня емпатичних здібностей В. Бойко, “Шкала емоційного відгуку" (BEES) А. Меграбян, Н. Епштейн, Анкета для батьків ЗОІППО.

Мета статті полягає полягає у визначені значення та реалізації психологічного супроводу формування емпатично-толерантного ставлення шкільного батьківського колективу до дітей з психофізичними порушеннями в загальноосвітній школі з інклюзивною освітою.

Виходячи $з$ розуміння мети роботи, сформулюємо завдання статті:

1) теоретично обгрунтувати особливості діяльності практичного психолога 3 формування емпатично-толерантного ставлення батьків учнівського колективу до дітей з психофізичними порушеннями в загальноосвітній школі з інклюзивною освітою;

2) уточнити базові поняття дослідження: емпатичне ставлення, толерантне ставлення, психологічний супровід;

3) провести власне експериментальне дослідження 3 метою вивчення особливостей психологічного супроводу емпатичнотолерантного ставлення батьків учнівського колективу до дітей 3 психофізичними порушеннями в загальноосвітній школі з інклюзивною освітою;

4) теоретично обгрунтувати ефективні методи та прийоми формування емпатично- толерантного ставлення батьків учнівського колективу до дітей з психофізичними порушеннями.

\section{Виклад основного матеріалу до-} слідження. Міжнародні стандарти в галузі прав людини грунтуються на ідеї участі кожної особи в суспільному житті на засадах рівності й без дискримінації [2]. Україна як член міжнародного співтовариства ратифікувала основні міжнародні акти у сфері забезпечення прав дітей, які відображають світові стандарти освіти, соціального захисту та охорони здоров’я. Зокрема, у статті 24 «Освіта» Конвенції про права осіб з інвалідністю йдеться про обов'язок держави реалізувати інклюзивну модель освіти, яка б дозволила всім дітям бути рівними учасниками в житті суспільства та навчальному процесу відповідно до їх особливостей [1].

Проблема інтеграції в соціум, підвищення якості життя дітей 3 психофізичними порушеннями була і залишається актуальною. У нашій країні з кожним роком збільшується кількість дітей з важкими вродженими та набутими захворюваннями, що призводить до повної їх інвалідності. За статистикою в Україні налічується 135,4 тисячі дітей-інвалідів, або 120 осіб на кожні 10 тисяч дітей. Проте в Україні історично склалася така ситуація, за якої діти 3 особливими потребами протягом довготривалого часу залишалися поза увагою суспільства, і навіть певною мірою були ізольованими від нього, навчаючись та виховую- 
чись в школах-інтернатах. Часто ці діти виявлялись непідготовленими до життя у суспільстві, що аж ніяк не відповідало їхнім особливим потребам [9].

Результати досліджень багатьох вчених засвідчують, що розумовий, емоційний і соціальний розвиток дітей $з$ психофізичними порушеннями знаходиться у прямій залежності від позитивного ставлення до них, їх розуміння i прийняття вчителями, батьками і здоровими дітьми. Таке ставлення є однією із вихідних умов розв'язання проблем інклюзивного навчання, яке набуває все більшої значущості. Тому формування культури толерантності $€$ визначним. На думку багатьох вчених $\begin{array}{lrl}\text { C. Братченко, Н. Капустіна, } & \text { Н. Круглова, } \\ \text { В. Лекторський, } & \text { В. Петров, } & \text { М. Семашко, }\end{array}$ К. Уейн толерантність виявляється в прагненні людини досягти порозуміння з іншими, узгодити різні установки, мотиви, орієнтації, не вдаючись до насильства, придушення людської гідності. Проблема толерантності пов'язана 3 деструктивними діями, які $є$ наслідком нетерпимого ставлення (інтолерантності) [4]. Мельникова М. розглядала толерантність нетерпимість, як цілісний акт, що включає як відношення, так і подальші дії. Найчастіше, це припинення явища, іноді шляхом знищення його носія або ж, у більш м'якій формі, - відмова від контакту з ним (уникнення, відторгнення) [10].

У дослідженнях визначення емпатії А. Бодальова, П. Массена, Л.Журавльової та інших вчених, іiі розуміють як інтелектуальний процес пізнання іншої людини через аналіз іiі особистісних якостей. Представники другого напрямку Е. Титченер трактують емпатію як емоційний стан, що виникає у людини як відгук на переживання іншої особи, як здатність перейматися емоційним станом іншої людини. Існуючі механізми емпатії дозволяють людям доброзичливо і невимушено вести себе в суспільстві, стримувати негативні переживання, не показувати їх стороннім людям та допомагати тим, хто цього потребує. Встановлено, що емпатична здатність зростає з ростом життєвого досвіду, а також краще реалізується при подібності поведінки і емоційних реакцій суб'єктів [8].

У ході розвитку суспільства негативне ставлення до людей 3 психофізичними порушеннями формувалося поступово, як захисна реакція самозбереження нації або народності. Діти з тими чи іншими психофізичними порушеннями викликали і викликають особливе i не завжди адекватне ставлення. Існує безліч міфів у громадській свідомості, пов'язаних 3 природою і причинами відхилень у розвитку, спадковою схильністю до захворювання тощо. Забобони є складовою частиною нашої соціальної структури, і спроби позбутися від них можуть викликати глибоке внутрішній опір. Виродження генофонду автоматично викликає протест, який в сучасних умовах не може бути виправданий у силу того, що значна частина українського суспільства не приділяє належ- 
ної уваги власному здоров’ю та здоров'ю нації в цілому.

Одним 3 найпоширеніших стереотипних думок про дітей з обмеженими можливостями здоров'я $є$ уявлення про них як про людей хворих, залежних, неповноцінних. Так, будь-який дефект в розумінні більшості ставить людину в позицію нещасної, обмеженої людини. У свою чергу, дана суспільна установка викликає у осіб з обмеженими можливостями почуття психологічного дискомфорту, неповноцінності, ізольованості, нерозуміння. Величезний вплив на суспільну свідомість чинить сприйняття людини 3 психофізичними порушеннями як даремного члена суспільства, не здатного реалізувати себе ні в громадськості, ні в особистому житті. Дана позиція не тільки не гуманна, але й небезпечна. Спроби поділяти людей на “потрібних" i “непотрібних” порочні по своїй суті, бо їх реалізація породжує сваволю, що веде до деградації і людини, і суспільства. Проблеми освіти дітей $з$ психофізичними порушеннями у різних типах закладів вивчали І. Бєлякова, В. Бондар, А. Колупаєва, М. Малофєєв, Л. Масунова, Н. Назарова, М. Нікітіна, Б. Пузанов, Т. Свірідюк, Л. Солнцева, Н. Стадненко, Б. Шеремет, М.Шматко та ін. Ними досліджувались принципи, переваги та недоліки різних підходів до організації навчання, особливості реалізації варіантів навчання дітей відповідно до виду дизонтогенезу, динаміка змін освіти та її інноваційні тенден- ції тощо[11].

Аналіз теоретичних джерел дозволяє зробити висновок, що соціальна ситуація розвитку дітей $з$ психофізичними порушеннями в умовах різних типів закладів відрізняється, але першочергово залежить від ставлення до них:

1) Як до хворих. Відповідно до цієї моделі особи з психофізичними вадами є хворими і потребують лікування. Таке ставлення обмежує можливості дітей.

2) Недолюдина. Особа з психофізичними вадами розглядається як неповноцінна, внаслідок чого пропагується штучне обмеження ії взаємодії з іншими людьми.

3) Загроза суспільству. Деякі категорії осіб з психофізичними вадами вважаються загрозою для суспільства, тому пропонується їхня ізоляція.

4) Об’єкт жалю. У рамках цієї моделі до аномальної дитини ставляться як до маленької, опікують; для неї створюються комфортні умови, задовольняються усі потреби з обмеженням самостійності самої дитини.

5) Об’єкт обтяжливої благодійності. Витрати на утримання дитини 3 психофізичними порушеннями мають бути обов'язком суспільства.

6) Розвиток. Дитина 3 психофізичними порушеннями має ті ж права й обов'язки, що й здорова дитина, їй слід створювати умови для розвитку і самостійної адаптації в суспільстві [6]. 
Саме інклюзивна освіта є виявленням емпатично-толерантного ставлення суспільства до дітей з психофізичними порушеннями. Одними з учасників навчально-виховного процесу є батьки учнівського колективу, які формують у своїх дітей сприймання світу та ставлення до інших людей. Практика показує, що найбільш інтенсивно співпрацюють ті діти, батьки яких створили в родині сприятливий психологічний мікроклімат та служать для них прикладом доброзичливості і високої моральної культури [6]. Однією з умов, яка забезпечує ефективність інклюзивної освіти, є формування міжособистісних стосунків дітей з порушеннями психофізичного розвитку зі здоровими однолітками в інклюзивному закладі. Суттєвим аспектом цієї проблеми $є$ пошук шляхів та засобів подолання перешкод у процесі взаємодії учня з класом. Індивідуальні особливості психофізичного розвитку дітей з особливими потребами, стереотипи і неготовність педагогів, здорових школярів і учнів з вадами психофізичного розвитку, батьків обох категорій дітей зумовлюють значні труднощі у процесі формування системи соціальних взаємин учнів інклюзивного класу. Дуже важливо, щоб батьки добре усвідомлювали цільові установки виховання, в основі якого лежить необхідність громадського формування особистості, $\mathrm{i}$ звертали увагу не тільки на навчальну роботу дітей, а й на фізичне, моральне і естетичне виховання.

Дослідження, яке ми провели з батька- ми в загальноосвітній школі в інклюзивному та звичайному класах за такими методиками: тест комунікативної толерантності В. Бойко, експрес-опитувальник "Індекс толерантності"
Г. Солдатова,
О. Кравцова,
О. Хухлаєв, Л. Шайгерова, методика діагностики рівня емпатичних здібностей В. Бойко, “Шкала емоційного відгуку" (BEES) А. Меграбян, Н. Епштейн, Анкета для батьків ЗОІППО, показало наступні результати:

1. в звичайному класі відсутній високий рівень толерантності, на відміну в інклюзивному $-18 \%$;

2. рівень емпатійних здібностей у відсотковому значенні в обох класах не відрізняється;

3. в звичайному класі "за спільне навчання дітей обох категорій” 50\%, в інклюзивному 100\% батьків.

Все це дає можливість зробити висновок, що через брак інформації та стереотипні установки батьки звичайних дітей проти інклюзивного навчання.

Психологічний супровід передбачає цілеспрямовану, грамотно сплановану роботу 3 усіма категоріями учасників навчальновиховного процесу - вчителями, учнями, батьками, громадськістю $з$ дотриманням принципу наступності за основними напрямками:

- діагностична робота;

- профілактична та просвітницька діяльність;

- корекційно-відновлювальна та розви-

с Царькова О. В., Пономаренко В. В. 
вальна робота;

- консультаційна робота;

- організаційно-методична діяльність.

В першу чергу це можливо завдяки формуванню емпатично-толерантного ставлення батьків шкільного колективу батьків до дітей 3 психофізичними порушеннями. Саме емпатія - соціально-позитивна якість особистості, вона підтримується суспільними поривами життя, але може мати індивідуальний, вибірковий характер, коли відгукуються на переживання не будь-якої іншої людини, а тільки значимий. Основний формою відображення людиною оточуючої його дійсності є ставлення. У своїй роботі ми розглядаємо толерантність як особливе ставлення [5].

Психічно ставлення представляє собою систему індивідуальних, виборчих, усвідомлених чи неусвідомлених зв'язків індивіда з різними чинниками об'єктивної дійсності, наповнених оцінками цих факторів .

У центрі уваги психологічної служби знаходяться діти і підлітки $з$ різними відхиленнями в психічному, соматичному, сенсорному, інтелектуальному, особистісному та соціальному розвитку, а також особи, які мають особливі освітні потреби, зумовлені порушеннями здоров'я.

Основною метою діяльності психологічної служби є виявлення, усунення та запобігання дисбалансу між процесами навчання i розвитку дітей з особливими освітніми потребами та їх індивідуальними можливостями, створення умов для соціально-психологічної адаптації, включаючи подальше професійне самовизначення учнів.

Саме тому головними завданнями практичного психолога в формуванні емпатичнотолерантного ставлення шкільного колективу батьків до дітей з психофізичними порушеннями є:

1. формування адекватних психологічних установок в ставленні до дітей;

2. формування ставлення до дитини, як до людини з потенціалом;

3. формування прийняття дитини такою, яка вона $€$.

Умовою реалізації потенційних можливостей дітей $\epsilon$ створення для кожного учня сприятливої соціально-психологічної обстановки довіри і доброзичливості, зняття страху і неприйняття навчальної ситуації, організація співробітництва та забезпечення свободи вибору сфери діяльності для соціалізованих форм самовиявлення.

В рамках роботи по формуванню емпатично-толерантного ставлення до дітей з психофізичними порушеннями психолог здійснює наступні види діяльності:

1. Діагностика:

- оцінка навчальної та соціального мікросередовища для організації оптимальних умов навчання і розвитку дитини;

- вивчення особливостей когнітивної, емоційно-вольової, комунікативноповедінкової та особистісної сфер дитини 3 
відхиленнями у розвитку;

- вивчення особистісних особливостей батьків дітей з особливими потребами;

2. Консультування:

- психологічна просвіта вчителів, вихователів, батьків обох категорій.

- консультування i надання допомоги педагогам, вихователям у реалізації індивідуальних розвивальних програм, організації взаємодії між дітьми у навчальному процесі та за його межами;

- психологічне консультування сімей, спрямований на оптимізацію доброзичливої атмосфери, формування адекватного виховного підходу до дитини з проблемами в навчанні, покращення емоційного контакту 3 ним, співвіднесення можливостей дитини з вимогами навчального процесу;

- професійна орієнтація підлітків і молоді з вадами розвитку;

3. Корекція:

- проведення занять 3 корекції емоційно -вольових, комунікативно-поведінкових і особистісних порушень, виявлених у «особливих» дітей;

- розробка методичних рекомендацій, спрямованих на корекцію виявлених порушень у дітей 3 подальшим ознайомленням вчителів з аналізом отриманих даних;

- надання психологічної підтримки батькам дітей, що мають відхилення у розвитку. Форми організації психокорекційної роботи:
Консультативно-рекомендаційна (рекомендації ПМПК);

- Інформаційно-просвітницьку (лекції, семінари, батьківські збори, стенди, інформаційні куточки для батьків);

- Практичні заняття для батьків (індивідуальні, групові);

- Організація «круглих столів», батьківських конференцій, семінарів, клубів, робота 3 батьківською групою;

- Організація дозвілля (дитячих свят та ранків, конкурсів і розваг);

- Індивідуальні заняття з батьками та їх дитиною;

- Тренінги та психокорекційні заняття.

Психолог навчального закладу об'єднує у своїй діяльності три функціональні навантаження і працює $з$ трьома суб'єктами: дітьми, педагогами та батьками обох категорій [12].

Через це, психологу недостатньо мати спеціальну підготовку. Навпаки, його професіограма має відповідати стандартам, які б забезпечували виконання ними освітніх, навчальних, виховних, діагностичних, прогностичних, профілактичних та основних: превентивно-корекційних і психопедагогічних корекційних функцій незалежно від типу закладів, які відвідує дитина, - чи то соціальнореабілітаційні центри, чи спеціальні дошкільні або шкільні заклади тощо.

Висновки. Проблема толерантності та емпатії сьогодні - одна з центральних проблем як глобального, так і національного порядку. 
Стабільність і благополуччя світу в третьому тисячолітті багато у чому залежить від здатності людей проявляти терпимість, поважати інші культурні і соціальні особливості, бажання зрозуміти один одного i співпрацювати, шукати й знаходити шляхи врегулювання соціокультурних конфліктів. Емпатія дозволяє осягнути сутність іншого. Не стільки зрозуміти, скільки уловити таємні рухи його душі: суть мотивів і сенс вчинків, джерела інтересів або апатій, причини брехні або щирості, цілі замкнутості або розбещеності і т.д. Толерантність у багатьох випадках допомагає попередити конфлікт або спрямовує його розвиток до конструктивного вирішення при врахуванні інтересів обох сторін. Слід також відзначити роль, так званих, афективної i фрустраційної толерантності у подоланні бурхливих емоційних станів, характерних для міжособистісного конфлікту. При цьому толерантність впливає на поведінку суб'єкта опосередковано - через ті акценти, які він вирізняє у своїх уявленнях про конфлікт та які слугують джерелом його негативних емоційних станів, що, в свою чергу, виступають мотивами розгортання конфліктної поведінки.

Образ дитини з психофізичними порушеннями і пов'язаний з цим ступінь невідповідності йому звичайній дитини багато в чому визначається загальними цінностями та установками суспільства. Індивідуальні особливості психофізичного розвитку дітей з особливими потребами, стереотипи і неготовність педа- гогів, здорових школярів і учнів 3 порушеннями у психофізичному розвитку, батьків обох категорій дітей зумовлюють значні труднощі у процесі формування системи соціальних взаємин учнів інклюзивного класу.

Стереотипи, страхи, заборони, сором, відсутність знань, невірна інформація - все це сприяє розвитку негативного ставлення до дітей з обмеженими можливостями здоров'я та життєдіяльності, а особливо до інвалідів. Подібне ставлення присутній на всіх рівнях: у батьків, вчителів, в школах, у чиновників і навіть у самих дітей з обмеженими можливостями. Поява статті в газеті, журналі, телепередачі про таких людей, їх інтересах, проблемах, можливості самореалізації до недавнього часу було рідкістю.

Саме психологи (“інженери людських душ”) створюють відповідні умови доброзичливості і поваги людей один до іншого( особливо до дітей) в суспільстві шляхом створення позитивних установок та успішних результатів спільної діяльності людей незалежно від їх статусів та діагнозів.

\section{Перспективи подальших досліджень} у даному напрямі полягають у вивченні залежності психічного та фізичного стану дітей з психофізичними порушеннями від емпатичнотолерантного ставлення до них. Визначення необхідності впровадження єфективного психологічного супроводу щодо консультативнопросвітницької роботи психолога 3 шкільним колективом батьків. 


\section{Перелік використаних джерел:}

1. Закон України «Про освіту» щодо особливостей доступу осіб $з$ особливими освітніми потребами до освітніх послуг // Відомості Верховної Ради України, 2017 р., № 37-38, ст. 2017;

2. Конвенція про захист прав людини і основоположних свобод: з поправками, внесен. відповідно до положень Протоколів №№ 11 та 14 з Протоколами №№ 1, 4, 6, 7, 12 та 13) // Право України. - 2010. - № 10. - С. 215-233.

3. Аксенова Л.И. Правовые основы специального образования и социальной защиты детей с отклонениями в развитии / Л.И. Аксенова // Дефектология. - 2007. - №1. - C. 3-10.

4. Андрєєв М.В. Категорія «толерантність» і система сучасної освіти / М.В. Андрєєв // Розвиток особистісного потенціалу та професійних навичок майбутнього фахівця: зб. наук. праць / За заг. ред. Г.С. Гребенюка; Мін-во мистецтва і туризму України. Луганськ. держ. інст.культури і мистецтва. Обл. метод. кабінет учб. закладів мистецтва та культури. -Харків: Стиль Іздат, 2006. -264 c. - C. 9-15.

5. Душка А.Л. Индивидуально-психологические особенности личности с психофизическими отклонениями [Електронний ресурс] / А.Л. Душка // Науковий вісник Південноукраїнського національного педагогічного університету ім. К.Д. Ушинського. - 2013. - № 7-8. C. 58-65.

6. Елен Р. Даніелс і Кей Стаффорд. Залучення дітей $з$ особливими потребами до системи загальноосвітніх класів. - Л.: Товариство «Надія», 2000. - 256 с.

7. Железняк Л.С. Опыт включения детей с проблемами развития в состав психотерапевтических групп / Л.С. Железняк, И.Б. Карвасарская. - Обозрение психиатрии и медицинской психологии им. В.М. Бехтерева, 2003. - С. 102-104.

8. Журавльова Л.П. Емпатійні ставлення та їх класифікація / Л.П. Журавльова // Соціальна психологія. - 2008. - № 5(31). - С. 39-46.

9. Інвалід і суспільство: проблеми інтегращіï. Збірник теоретичних та методичних матеріалів для працівників соціальних служб для молоді / І.Д. Звєрєва, І.Б. Іванова. - К.: А.Л.Д., 1995. - 96 с.

10. Капустина Н. Формирование толерантности в структуре этического мировоззрения // Известия Уральского государственного университета. - 2008. - № 60. - С. 6169.

11. Пашков А.Г., Гонеев А.Д. Педагогические основы социальной реабилитации детей с ограниченными возможностями. - Курск: Изд-во КГМУ, 1999. - 224 с.

12. Управление образовательным учреждением, осуществляющим интегрированное образование детей с ограниченными возможностями здоровья. Методическое пособие для руководителей образовательных школ / Курс «Интегрированное обучение детей с особыми образовательными потребностями» - Самара: Издво ЦСО, 2004. - 80 с.

\section{References (Transliteration):}

1. Zakon Ukrainy «Pro osvitu» shchodo osoblyvostei dostupu osib z osoblyvymy osvitnimy potrebamy do osvitnikh posluh // Vidomosti Verkhovnoi Rady Ukrainy, 2017 r., № 37-38, st. 2017;

2. Konventsiia pro zakhyst prav liudyny i osnovopolozhnykh svobod: z popravkamy, vnesen. vidpovidno do polozhen Protokoliv №№ 11 ta 14 z Protokolamy №№ 1, 4, 6, 7, 12 ta 13) // Pravo Ukrainy. - 2010. - № 10. - S. 215-233.

3. Aksenova L.Y. Pravovыe osnovы spetsyalnoho obrazovanyia y sotsyalnoi zashchytы detei s otklonenyiamy v razvytyy / L.Y. Aksenova // Defektolohyia. - 2007. - №1. - S. 3-10.

4. Andrieiev M.V. Katehoriia «tolerantnist» i systema suchasnoi osvity / M.V. Andrieiev // Rozvytok osobystisnoho potentsialu ta profesiinykh navychok maibutnoho fakhivtsia: zb. nauk. prats / Za zah. red. H.Ie. Hrebeniuka; Min-vo mystetstva i turyzmu Ukrainy. Luhansk. derzh. inst.kultury i mystetstva. Obl. metod. kabinet uchb. zakladiv mystetstva ta kultury. -Kharkiv: Styl Izdat, 2006. - 264

(C) Царькова О. В., Пономаренко В. В. 
S. - S. 9-15.

5. Dushka A. L. Yndyvydualno-psykholohycheskye osobennosty lychnosty s psykhofyzycheskymy otklonenyiamy [Elektronnyi resurs] / A.L. Dushka // Naukovyi visnyk Pivdennoukrainskoho natsionalnoho pedahohichnoho universytetu im. K.D. Ushynskoho. 2013. - № 7-8. - S. 58-65.

6. Elen R. Daniels $i$ Kei Stafford. Zaluchennia ditei $\mathrm{z}$ osoblyvymy potrebamy do systemy zahalnoosvitnikh klasiv. - L.: Tovarystvo «Nadiia», 2000. - $256 \mathrm{~s}$.

7. Zhelezniak L.S. Opyt vkliuchenyia detei s problemamy razvytyia $\mathrm{V}$ sostav psykhoterapevtycheskykh hrupp / L.S. Zhelezniak, Y.B. Karvasarskaia. - Obozrenye psykhyatryy y medytsynskoi psykholohyy ym. V.M. Bekhtereva, 2003. S. 102-104.

8. Zhuravlova L.P. Empatiini stavlennia ta yikh klasyfikatsiia / L.P. Zhuravlova // Sotsialna psykholohiia. 2008. - № 5(31). - S. 39-46.

9. Invalid $i$ suspilstvo: problemy intehratsii. Zbirnyk teoretychnykh ta metodychnykh materialiv dlia pratsivnykiv sotsialnykh sluzhb dlia molodi / I.D. Zvierieva, I.B. Ivanova. - K.: A.L.D., 1995. - 96 s.

10. Kapustyna N. Formyrovanye tolerantnosty v strukture эtycheskoho myrovozzrenyia // Yzvestyia Uralskoho hosudarstvennoho unyversyteta. - 2008. - № 60. - S. 6169.

11. Pashkov A.H., Honeev A.D. Pedahohycheskye osnovy sotsyalnoi reabylytatsyy detei s ohranychennumy vozmozhnostiamy. - Kursk: Yzd-vo KHMU, 1999. - 224 s. 12. Upravlenye obrazovatelnыm uchrezhdenyem, osushchestvliaiushchym yntehryrovannoe obrazovanye detei s ohranychennыmy vozmozhnostiamy zdorovia. Metodycheskoe posobye dlia rukovodytelei obrazovatelnыkh shkol / Kurs «Yntehryrovannoe obuchenye detei s osobыmy obrazovatelnыmy potrebnostiamy» - Samara: Yzd-vo TsSO, 2004. - 80 s.

\section{Tzarkova Olga}

Doctor of science (Psychology), associate Professor of Department of psychology of Melitopol State Pedagogical University, Melitopol (Ukraine)

\section{Ponomarenko Victoria}

Student of Department of psychology of Melitopol State Pedagogical University, Melitopol (Ukraine)

\section{PSYCHOLOGICAL SUPPORT FOR FORMATION OF AN EMPATHY-TOLERANT ATTITUDE OF THE PARENT'S SCHOOL STAFF TOWARDS CHILDREN WITH PSYCHOPHYSICAL DISORDERS}

\section{ABSTRACT}

The spread of inclusive education of children with physical and/or mental disabilities in Ukraine is not only a reflection of time, but also a step towards the full realization of the rights of children with mental and physical disabilities to quality education.

Such authors as A. Duska, G. Maize, V. Sorokin, V. Tzarkova in their works reveal the psychological problem of parent's attitude to their children with psychophysical disorders. But in the scientific literature, the question of the psychologist's tasks with the provision of educational and advisory assistance to the parent's school staff in the formation of empathic and tolerant attitude to children with psychophysical disorders is covered quite limited. The problem of tolerance and empathy today is one of the central problems of both global and national order. The stability and wellbeing of the world in the third Millennium depend 
to a large extent on the ability of people to be tolerant, to respect other cultural and social characteristics, to understand and cooperate, to seek and find solutions to sociocultural conflicts. Empathy allows us to understand the essence of the other. Not so much to understand how to catch the secret movements of his soul: the essence of motives and the meaning of actions, sources of interest or apathy, the causes lie or sincerity of purpose of closed or abandon, etc.

The study of the practical state of the problem of inclusion confirmed the urgent need for a special organization of the social environment for the inclusion of children with mental and physical disabilities in joint activities with healthy peers in educational institution.

One of the participants of the educational process are the parents of the student group, which form the children's perception of the world and attitude to other people. Practice shows that the most intensively cooperate those children whose parents have created a favorable psychological climate in the family and serve as an example of goodwill and high moral culture .

The purpose of the article is to determine the value and implementation of psychological support of empathic and tolerant attitude of the school parent team to children with psychophysical disorders in secondary school with inclusive education.

Based on the understanding of the purpose of the work, we formulate the objectives of the article:
1) to theoretically substantiate the features of the practical psychologist on the formation of empathy-tolerant attitude of parents of the student group to children with psychophysical disorders in ordynary school with inclusive education;

2) clarify the basic concepts of research: empathic attitude, tolerant attitude, psychological support;

3) to conduct its own experimental study to study the features of psychological support of empathic and tolerant attitude of parents of the student group to children with psychophysical disorders in secondary school with inclusive education;

4) to theoretically substantiate effective methods and techniques of forming empaticotolerant attitude of the parents of the student team for children with mental and physical disabilities.

The study, which we conducted with parents in secondary school in an inclusive and regular classes on the following methods: test of communicative tolerance V. Boyko, Express questionnaire "tolerance Index" G. Soldatov, A. Kravtsov, A. Huhlaev, L. Shaigerova, methods of diagnosis of the level of empathic abilities V. Boyko, "scale of emotional response" (BEES). Mehrabyan, N. Epstein, Questionnaire for parents, showed the following results:

in a normal class there is no high level of tolerance, unlike in an inclusive class $-18 \%$;

2 . the level of empathic abilities in percentage value in both classes does not differ;

3 . in the normal class "for coeducation of 
children of both categories" $50 \%$, inclusive $100 \%$ of parents.

All this makes it possible to conclude that due to the lack of information and stereotypes

parents of ordinary children against inclusive education.

Psychological support involves purposeful, well-planned work with all categories of participants of the educational process-teachers, students, parents, the public in compliance with the principle of continuity in the main areas:

- diagnostic work;

- preventive and educational activities;

- correction rehabilitation and educational work;

- consulting work;

- organizational and methodological activities.

That is why the main tasks of the practical psychologist in the formation of empathic and tolerant attitude of the school team of parents to children with psychophysical disorders is:

1. the formation of adequate attitudes concerning children;

2. formation of the attitude to the child as to the person with potential;

3. formation of the adoption of the child as it is.

Key words: empathic attitude, tolerant attitude, psychological support, integration of children with psychophysical disorders.

\section{Царькова Ольга Викторовна}

Доктор психологических наук, дочент кафедры психологии Мелитопольского государственного университета имени Б. Хмельницкого, г. Мелитополь (Украина)

\section{Пономаренко Виктория Викторовна}

Студентка кафедры психологии Мелитопольского государственного университета имени Б. Хмельницкого, г. Мелитополь (Украина)

\section{ПСИХОЛОГИЧЕСКОЕ СОПРОВОЖДЕНИЕ ФОРМИРОВАНИЯ ЕМПАТИЧНО-ТОЛЕРАНТНОГО ОТНОШЕНИЯ ШКОЛЬНОГО КОЛЛЕКТИВА РОДИТЕЛЕЙ К ДЕТЯМ С ПСИХОФИЗИЧЕСКИМИ НАРУШЕНИЯМИ}

Аннотация. Распространение в Украине процесса инклюзивного образования детей с ограниченными возможностями физического и/или психического здоровья является не только отражением времени, но и представляет собой еще один шаг к обеспечению полной реализации прав детей с психофизическими нарушениями на качественное образование.

Такие авторы, как А. Душка, Г. Кукуруза, В. Сорокин, В. Царькова в своих трудах раскрывают психологическую проблему отношения родителей к своим детям, имеющим психофизические нарушения. Но в научной литературе вопрос относительно выполнения психологом задач в оказании просветительской и консультативной помощи именно школьному коллективу родителей в формировании емпатично-толерантного отношения к детям с психофизическими нарушениями 
освещается достаточно ограничено. Проблема толерантности и эмпатии сегодня - одна из центральных проблем как глобального, так и национального порядка. Стабильность и благополучие мира в третьем тысячелетии во многом зависит от способности людей проявлять терпимость, уважать иные культурные и социальные особенности, желания понять друг друга и сотрудничать, искать и находить пути урегулирования социокультурных конфликтов. Эмпатия позволяет постичь сущность другого. Не столько понять, сколько уловить тайные движения его души: суть мотивов и смысл поступков.

Изучение практического состояния проблемы инклюзии подтвердило насущную необходимость специальной организации социальной среды для включения детей с психофизическими нарушениями в совместную деятельность со здоровыми сверстниками в общеобразовательном учреждении.

Одними из участников учебновоспитательного процесса являются родители ученического коллектива, которые формируют у детей восприятие мира и отношение к другим людям. Практика показывает, что наиболее интенсивно сотрудничают те дети, родители которых создали в семье благоприятный психологический микроклимат и служат для них примером доброжелательности и высокой нравственной культуры .

Цель статьи заключается в определении значения и реализации психологического сопровождения формирования емпатичнотолерантного отношения школьного родительского коллектива к детям с психофизическими нарушениями в общеобразовательной школе с инклюзивным образованием.

Исходя из понимания цели работы, сформулируем задачи статьи:

1) теоретически обосновать особенности деятельности практического психолога по формированию емпатично-толерантного отношения родителей ученического коллектива к детям с психофизическими нарушениями в общеобразовательной школе с инклюзивным образованием;

2) уточнить базовые понятия исследования: эмпатичное отношение, толерантное отношение, психологическое сопровождение;

3) провести собственное экспериментальное исследование с целью изучения особенностей психологического сопровождения емпатично-толерантного отношения родителей ученического коллектива к детям с психофизическими нарушениями в общеобразовательной школе с инклюзивным образованием;

4) теоретически обосновать эффективные методы и приемы формирования емпатично-толерантного отношения родителей ученического коллектива к детям с психофизическими нарушениями.

Исследование, которое мы провели с родителями в общеобразовательной школе в инклюзивном и обычном классах по следующим методикам: тест коммуникативной толе- 
рантности В. Бойко, экспресс-опросник “Индекс толерантности” Г. Солдатова, А. Кравцова, А. Хухлаєв, Л. Шайгерова, методика диагностики уровня эмпатически способностей В. Бойко, “Шкала эмоционального отклика" (BEES). Меграбян, Н. Эпштейн, Анкета для родителей ЗОІППО, показало следующие результаты:

1. в обычном классе отсутствует высокий уровень толерантности, в отличие в инклюзивном - 18\%;

2. уровень эмпатических способностей в процентном значении в обоих классах не отличается;

3. в обычном классе "за совместное обучение детей обоих категорий” $50 \%$, в инклюзивном $100 \%$ родителей.

Bсе это дает возможность сделать вывод, что из-за нехватки информации и стереотипных установок родители обычных детей против инклюзивного обучения.

Психологическое сопровождение предполагает целенаправленную, грамотно спланированную работу со всеми категориями участников учебно-воспитательного процесса - учителями, учениками, родителями, общественностью с соблюдением принципов по основным направлениям: - диагностическая работа; - профилактическая и просветительская деятельность; - коррекционновосстановительная и развивающая работа; консультационная работа; - организационнометодическая деятельность.
Именно поэтому главными задачами практического психолога в формировании емпатично-толерантного отношения школьного коллектива родителей к детям с психофизическими нарушениями является: 1. формирование адекватных психологических установок в отношении детей; 2. формирование отношения к ребенку, как к человеку с потенциалом; 3. формирование принятие ребенка таким, какой он есть.

Ключевые слова: эмпатичное отношение, толерантное отношение, психологическое сопровождение, интеграция детей с психофизическими нарушениями.

\section{Дата отримання статті: 01.04 .2018 Дата рекомендації до друку: 09.05.2018 Дата оприлюднення: 24.05.2018}

